RADIATION AND REVOLUTION 
THOUGHT IN THE ACT A series edited by Brian Massumi and Erin Manning 


\section{RADIATION AND REVOLUTION}

Sabu Kohso 
(C) 2020 Duke University Press All rights reserved Printed in the United States of America on acid-free paper $\infty$

Text designed by Amy Ruth Buchanan Cover designed and illustrated by Skillet Gilmore

Typeset in Arno and Trade Gothic by Copperline Book Services

Library of Congress Cataloging-in-Publication Data Names: Kōso, Iwasaburō, [date] author. Title: Radiation and revolution / Sabu Kohso.

Other titles: Thought in the act.

Description: Durham : Duke University Press, 2020. |

Series: Thought in the act | Includes bibliographical references and index.

Identifiers: LCCN 2019055652 (print) | LCCN 2019055653 (ebook) ISBN 9781478009948 (hardcover) ISBN 9781478011002 (paperback) ISBN 9781478012535 (ebook)

Subjects: LCSH: Fukushima Nuclear Disaster, Japan, 2011. | Nuclear energy_Social aspects_Japan. | Nuclear energy-Political aspects-Japan.

Classification: LCC HV623 2011 .F85 K67 2020 (print) | LCC HV623 2011 .F 85 (ebook) | DDC 363.17/990952117-dc23

LC record available at https://lccn.loc.gov/2019055652 LC ebook record available at https://lccn.loc.gov/2019055653 
It may be that believing in this world, in this life, becomes our most difficult task, or the task of a mode of existence still to be discovered on our plane of immanence today. —Gilles deleuze and fÉlix guattari, What Is Philosophy?

I'm not referring here to the microapocalypse of death: everybody dies, and even if everybody dies at the same time (I mean everybody), what's the problem? The earth becomes a cleared tape and why should the angels grieve? -GEORGE CAFFENTZIS, In Letters of Blood and Fire

Emancipate yourselves from mental slavery None but ourselves can free our minds Have no fear for atomic energy 'Cause none of them can stop the time - в O B maRley, "Redemption Song" 
This page intentionally left blank 